\title{
Protection of Human Rights in the Amendment of the 1945 Constitution of The Republic of Indonesia
}

\author{
Harisman Harisman ${ }^{1}$ \\ ${ }^{1}$ Faculty of Law, Universitas Muhammadiyah Sumatera Utara, Indonesia \\ ${ }^{*}$ Corresponding author. Email harisman@umsu.ac.id
}

\begin{abstract}
The inclusion of human rights arrangements in the 1945 Amendment Constitution does not mean that human rights have been fully fulfilled. Many human rights problems still need serious attention from various parties, not only the state and the government but also the community and individuals. The amendment of the 1945 Constitution clearly determines the kinds of human rights that must be respected, protected, and fulfilled. Moreover, human rights in the Amendment of the 1945 Constitution are closely related to the regulation of basic individual rights and citizens' rights. However, it is very difficult to distinguish between the two types of rights due to the differences in grouping in the placement of the arrangement. Thus, this paper is intended to describe the efforts made to guarantee the protection of human rights through the 1945 Amendment Constitution. For this reason, legal research is carried out using a normative juridical approach through the use of secondary data while the results are analyzed qualitatively. The study revealed that human rights in the Amendment of the 1945 Constitution are categorized as constitutional rights divided into two categories, human rights and citizen rights. Human rights are owned by all residents, while the rights of citizens are owned by the citizens. This does not mean that the rights of citizens are not included as human rights but are only given and enforced limitedly to citizens. Those who are not citizens are not granted this kind of human rights, but they are limited to human rights in the form of basic individual rights. These two rights have been included in the 1945 Amendment in a different section. Human rights are regulated in Article 28 A to Article $28 \mathrm{~J}$, while citizens' rights can be seen in Article 27, Article 29 paragraph (2), Article 30 paragraph (1), Article 31, Article 33, and Article 34. With the inclusion of human rights and citizens' rights in the 1945 Amendment, which the state promises to its inhabitants, it is appropriate to guarantee protection in its fulfillment. The amendment of the 1945 Constitution implies that the protection of human rights and citizens' rights as constitutional rights can be carried out in several ways, namely: 1) implementing the principles of a democratic rule of law, 2) guaranteeing regulation through legislation, 3) implementing the obligation for everyone to respect for the human rights of others, and 4) the application of the principle of responsibility for human rights not only to the state - the government but also every individual.
\end{abstract}

Keywords: protection, human rights, the amendment of the 1945 Constitution. 


\section{INTRODUCTION}

Human rights have been discussed for a long time, although it is still causing debate today. The notion of a "right" is still considered controversial and raises philosophical debates. (Thohari, 2016, p. 2) Even though there have been formal juridical agreements both internationally and nationally regarding various forms of human rights, as stated in Declaration of Human Rights 1984 and The 1945 Constitution of The Republic of Indonesia.

The inclusion of human rights issues in the constitution shows the importance of human rights as something that must be upheld and protected by all parties in the nation, from the state, society, and government. The guarantee of human rights must be clearly stated in the constitution or written state of the constitution (Asshiddiqie, 2014, p. 343). This is in accordance with the concept of the rule of law (rechtstaat), which requires the protection of human rights as one of the characteristics it must have.

Likewise, the 1945 Constitution Amendments have included human rights provisions that are intended to mention individual rights and the rights of citizens. Although the Amendment of the 1945 Constitution does not explicitly state the differences between the two rights, it often creates problems in their implementation. Not all rights of citizens can be owned by every individual, even though both are human rights that must be upheld, respected, and protected. Moreover, the Amendment of the 1945 Constitution contains separate regulatory chapters on human rights, which are not combined in the provisions concerning the chapter on citizens and residents.

The existence of such arrangements does not mean that it does not cause problems in its implementation. The government is sometimes accused of being inadequate or even unable to fulfill and protect what constitutes the human rights of individual citizens. The government is sometimes accused of limiting or depriving citizens of their human rights through the formation of legal products under the constitution. Moreover, the inclusion of human rights in the constitution is a form of the government's promise to its citizens, which must be fulfilled and kept. The inability to fulfill and provide protection for the human rights of citizens as stated in the constitution can cause problems, especially in relation to the lack of public trust in the government.

Human rights are constitutional rights, basic rights that every human being must own. The government should be able to guarantee the protection and fulfillment of human rights as constitutional rights of citizens. Based on this, they seek to answer the question of how to protect human rights in the constitution?

\section{RESEARCH METHOD}

This research is legal research that uses a normative juridical approach with a focus on legislation or a statute approach. The specification of this research is descriptive by describing the results of the analysis on the formulated problems. The data used is in the form of secondary data obtained from the literature, which includes the Amendment of the 1945 Constitution, books, and journal articles that are related to the discussion in this study. The data collected is analyzed qualitatively in order to answer the problems.

\section{FINDINGS AND DISCUSSION}

\subsection{The Importance of Human Rights}

There has been no uniformity about the notion of universal human rights, according to their respective views. However, Indonesia, as a country that has a commitment to human values as contained in the principles of Pancasila and the Preamble of the 1945 Constitution, has provided formal juridical limitations through Law Number 39 of 1999 concerning Human Rights as follows:

Article 1 number (1):

"Human rights are a set of rights inherent in the nature and existence of humans as creatures of God Almighty and are His gifts which must be respected, upheld, and protected by the state, law, government and everyone for the sake of honor and protection of dignity."

Based on the definition above, it is illustrated that there are several elements in understanding human rights that are important to pay attention to, including 1) Who owns the rights; 2) Where does that right come from; 3) Who is the person in charge of rights, and 4) What is the purpose of respecting and protecting these rights

Based on the definition of the above definition, it should be used as a guide for all citizens, especially in Indonesia, in understanding human rights. The formulation is in line with the perspective and attitude of the Indonesian people in understanding human rights. It is based on religious teachings, universal moral values, and noble national cultural values, Pancasila, and the 1945 Constitution as stated in the Decree of the Indonesian People's Consultative Assembly Number: XVII / MPR / 1998 on Human Rights. 
Referring to the definition above, it is recognized that every individual without exception has human rights that must be respected by anyone and in any situation. Once these rights are exercised by everyone, there will be simultaneous "obligations" and "responsibilities". It means that every individual exercising their human rights must pay attention to the human rights of others as an obligation and responsibility.

Likewise, the state and its government - as the holder of the highest power is not the right giver but as the protector of the rights given by God to humans as citizens and non-citizens. The state - the government - has never granted human rights to every citizen. The government has the main responsibility to provide protection and fulfillment. The human rights that everyone has come from God Almighty. In this context, the presence of the state the government - does not mean that it is the only one responsible for protecting human rights, including society and individuals. James W Nickel emphasized that "states and individuals alike have obligations relating to human rights." (Nickel, 1996, p. 61) Even though it is expressly stated in Article 28, I paragraph (4) of the 1945 Constitution Amendment that the main person responsible for human rights is the government.

Basically, human rights are basic rights that every human being owns, which have a role in protecting human dignity. The main focus of human rights is life and human dignity (Riyadi, 2018, p.1). Humans without rights will not get their dignity and worth. To be a human being, one must have rights; without human rights, one is not human. Moreover, human rights can be viewed as a set of rights that are placed as a normative element that has the function of providing and protecting important freedoms, powers, immunities, protections, opportunities, and benefits (Nickel J. W., 1996, p. 51). Thus, rights are defined as standards of behavior for the government and society, and even individuals in maintaining human dignity.

\subsection{Position and Role of the Constitution}

The use of the constitutional term from the point of history has long been known since the days of Ancient Greece (Tutik, 2010, p. 86). Likewise, the understanding of the "constitution" has developed according to its zoning. Even today, scholars have different interpretations regarding the meaning of the constitution (Sihombing, 2019, p. 2). Initially, there were two different terms referred to the constitution, Politeia as in Ancient Greek and constitution as in Latin. The term constitution is divided into two definitions. First, constitution is defined in a broad sense consisting of a written constitution such as constitutional law and constitutional conventions. Second, a constitution, in a narrow sense such as The 1945 Constitution of Indonesia.

Basically, constitution is a form of agreement formed by the rulers and the people in the nation and state to prevent and limit the occurrence of arbitrariness over the power they have. The power possessed by the government has been stipulated in the constitution and the government cannot take any action it wants beyond what has been determined in the constitution (Charda, 2017, p. 124). Moreover, the existence of a constitution is based on the existence of a general agreement or a general agreement of all citizens with regard to the state. Lord Bryce noted that there are four motives for the emergence of a constitution (Tutik, Indonesian Constitutional Law Construction Post Amendment to the 1945 Constitution, 2010, p.65)

1) The desire of citizen members to guarantee their rights which may be threatened and at the same time limit the actions of the authorities;

2) There is a desire from those who are ruled or those who govern in the hope of guaranteeing their people by determining the form of a certain constitutional system;

3) There is a desire from the founder of the new state to guarantee the procedures for the administration of the state administration;

4) There is a desire to ensure effective cooperation between states.

Moreover, seen from its content, Sri Soemantri stated that in general, the constitution contains three main points as follows: (H. Dahlan Thaib, Jazim Hamidi, Hj. Ni'matul Huda, 2003, p. 18)

1) There is a guarantee for the rights of human beings and citizens;

2) Establishing the constitutional structure of a country which is fundamental in nature;

3) There are a division and limitation of administrative duties, which are also fundamental in nature.

From the main motives and contents above, it can be seen that the constitution has a role as limiting power, as Kunardi explained that the constitution, seen from its function, is divided into two parts, dividing power within the state and limiting the power of the government or rulers in the country. Besides that, it is also used as a tool to guarantee the rights of citizens. (Dede Rosyada, A.Ubaidillah, Abdul Rozak, Wahdi Sayuti, M. Arskal Salim GP, 2003, p. 93) For this reason, the constitution in the 
life of the state acts as a foundation and basic guideline for administrators of a country, limiting government actions so as not to act arbitrarily authority, and provide guarantees for human rights as citizens. (Ahmad Jamalong, Sukino, Sulha, 2019, p. 89)

Judging from the meaning of the constitution, Eka N.A.M Sihombing can identify 3 (three) positions of the constitution of a country, namely:

1. Judging from its position as the basic law, the constitution contains basic norms that direct how the government gets the authority to organize the administration of state power;

2. In terms of the hierarchy of laws and regulations, the constitution as the highest law has a strong position;

3. The constitution as a legal and political document places a special position. In addition to its substance or content containing basic legal norms, it also contains a certificate for the birth of a new country, inspiration to realize the state and the law.

\subsection{Protection of Human Rights in the Constitution: UUD 1945 Amendments.}

The constitution is the highest rule in a country that includes human rights as one of its study materials. Jimlly Asshiddiqie argued that the modern state places human rights as the core material and has an important position in the constitution (Tohari, 2016 , p. 39). The placement of human rights in the constitution not only makes them fundamental rights but also as the highest constitutional rights (Bagir Manan; Susi Dwi Harijanti, 2016, p. 448)

A. Ahsin Tohari emphasized that human rights are closely related to the constitution or the basic laws of a country. Because the constitution does not merely determine the state's authority at the operational level, it becomes a means of guaranteeing the rights of those who are governed (Thohari, Constitutional Rights in Indonesian Constitutional Law, 2016, p. 5). The inclusion of human rights in the constitution is intended so that there is a strong guarantee for the protection of the right of the population, especially citizens' rights. In addition, human rights in the constitution are not only recognized as natural rights and legal rights but also as constitutional rights. (Bagir Manan; Susi Dwi Harijanti, 2016, p. 456)

The existence of a relationship that is built between the constitution and human rights gives rise to an idea called constitutional rights. Article 51 paragraph (1) of Law Number 24 of 2003 concerning the Constitutional Court provides that constitutional rights are rights regulated in the 1945 Constitution of the Republic of Indonesia. According to Maruarar Siahaan, apart from rights regulated in the constitution, constitutional rights are also rights arising from the obligations of the state and the obligations of citizens because rights and obligations cannot be separated from one another.

Although human rights are categorized as constitutional rights, because they have been included in the constitution, it does not mean that they have the same meaning as citizens' rights. Human rights are defined as rights inherent in every human person, so that they apply to all residents, namely: citizens and foreign citizens. Meanwhile, citizen rights only apply to citizens of a particular state. This means that human rights have a broader meaning than the rights of citizens.

Jimly Asshiddqie stated that not all "constitution rights" are synonymous with "human rights." There are constitutional rights of citizens which are not included in the definition of human rights. For example, the right of every citizen to hold a position in government is "the citizen's constitutional rights", but does not apply to everyone who is not a citizen. Therefore, not all "citizen's rights" are "human rights," but it can be said that all "human rights" are also "citizen's rights." (Asshiddiqie J., 2007)

Likewise, it can be seen from the use of the term "citizen rights" as "natural rights" which states human rights as rights owned by humans because they are born as humans. It indicates the position of the state as regulator of rights, not as guarding of human rights as it is placed in the international human rights protection system. This means that human rights have a broader meaning than the rights of citizens. Human rights exist from the time humans are born, whereas citizen rights arise when a person is bound to become a member of a state called a citizen.

Although constitutional rights can be distinguished from one side, it is difficult to distinguish from the other. In terms of fulfillment, both citizen's rights and human rights contain what is called collective rights and individual rights. Collective rights are a type of right that is fulfilled for the benefit of all. Meanwhile, individual rights are a type of right whose fulfillment is aimed at the interests of individuals personally as humans. In its administration, the 1945 Constitution places these two types of rights in different chapters. What is categorized as citizens' rights are also included as part of human rights arrangements, such as the right to education, the right to freedom of religion, and the right to freedom of expression. This shows that the 
1945 Amendment requires the fulfillment of citizens' rights, including human rights.

Although constitutional rights can be divided into two categories, the citizen rights and the human rights it creates an obligation for the state to protect them. The state - the government - is responsible for ensuring human rights protection as a constitutional right for its citizens. Majda El Muhtaj stated that the content of human rights in the 1945 Constitution is a form of constitutional guarantee commitment to law enforcement and human rights in Indonesia (Muhtaj, 2017, p. 104)

The categories of the human rights that are protected by the constitution as contained in Article 28 A to Article $28 \mathrm{~J}$ of the 1945 Constitution apply to each individual while Article 27, Article 29 paragraph (2), Article 30 paragraph (1), Article 31, Article 33, and Article 34 of the 1945 Constitution only apply to every citizen. Human rights regulated in the 1945 Constitution can also be grouped into two types of fulfillment: individual rights and collective rights. Although these kinds of human rights can be grouped based on the nature of their fulfillment, it does not mean that this grouping is essential. This is because individual rights and collective rights are related to one another.

This means that Indonesia not only guarantees the protection of human rights from citizens but also foreign citizens who are residents of Indonesia. Article 26 paragraph (2) of the 1945 Constitution determines that the population is Indonesian citizens and foreigners who reside in Indonesia. This means that the human rights arrangements in the amended UUD 1945 are enforced not only for citizens but also for foreign citizens who live and reside in Indonesian territory.

In order to guarantee the protection of human rights, the mandate of Article 28 I paragraph (5) of the 1945 Constitution requires the application of the principles of a democratic rule of law and guarantees of regulation through statutory regulations. A democratic rule of law is a rule of law that recognizes that the people are in power. According to the International Commission of Jurist Conference in Bangkok in 1965, one of the requirements of a democratic rule of law is the existence of state constitutional protection forits people, the existence of guarantees in law, and how to obtain protection regarding human rights constitutionally (Sunarno, p.42)

Bahder Johan stated that the rule of law and human rights could not be separated from one another. Because of the requirement for the rule of law to protect human rights, if human rights are not protected in a country, the country is not a constitutional state but a dictatorial state with a very authoritarian government. Some of the initiators of the rule of law concept such as Friedman. Kant, Stahl, and A.V. Dicey emphasized that human rights protection is an important substance in the rule of law. (Puspitasari, 2000, p. 55)

Protection of human rights in the rule of law is realized through normalizing rights in the constitution and laws, such as the enactment of Law Number 39 of 1999 concerning Human Rights and Law Number 26 of 2000 concerning Human Rights Courts. Providing protection of human rights by the state through the constitution and laws and regulations like this is very important and constitutes the transparency of the state's commitment to protecting its citizens. Like Article $28 \mathrm{~J}$ paragraph (2) of the 1945 Constitution, it is clear that the limitation of human rights can only be done through statutory regulations.

Other norms, as referred to in Article $28 \mathrm{~J}$ paragraph (1) of the 1945 Constitution, oblige everyone to respect others' human rights. This means that the constitution requires the state - the government - and every person or individual to guarantee the protection of others' human rights, although the 1945 Constitution clearly states that the party responsible for human rights is the state, especially the government.

The institutionalization of the protection of human rights like this is constitutionally based on the need for legal certainty for the population and the consequences of the substance of the constitution as the basic law to contain the principal issues in state administration (Puspitasari, 2000, p. 58). Likewise, the enforcement of human rights is through judicial bodies as the executor of judicial power (Nasution, 2011, p.10)

\section{CONCLUSION}

The 1945 Constitution Amendments in regulating human rights and citizens' rights should not be made into separate chapters. The rights of citizens are an inseparable part of human rights because these two rights are actually related to individual rights, which in their implementation are different. Human rights are given to every individual, and citizens' rights are also given to individuals as citizens. If this kind of arrangement continues, it will have an effect on its implementation. There will be an interpretation that human rights are different from the rights of citizens. Moreover, the regulation on the protection of human 
rights is contained in a different chapter from the regulation of the rights of citizens.

\section{REFERENCES}

[1]. Ahsin Thohari, Constitutional Rights in Indonesian Constitutional Law, Jakarta: Erlangga Publisher, 2016

[2].Ahmad Jamalong, Sukino, Sulha, Pancasila and Citizenship Education in Higher Education, Depok: PT. RajaGrafindo Persada, 2019

[3].Bahder Johan Nasution, State of Law and Human Rights, Bandung: Mandar Maju, 2011.

[4].Bagir Manan and Susi Dwi Harijanti, "Constitution and Human Rights", Padjadjaran Journal of Legal Studies, Vol. 3 No.3, 2016, Art. No.11606, doi: 10.22304 / pjih.v3.n3.a1

[5].Dede Rosyada, A. Ubaidillah, Abdul Rozak et al, Civic Education, Democracy, Human Rights, and Civil Society, Jakarta: Kencana Prenada Media, Jakarta, 2003

[6].Eko Riyadi, International, Regional and National Perspective Human Rights Law, Depok City: PT. RajaGrafindo Persada, 2018

[7].Eka N.A.M. Sihombing, Introduction to Constitutional Law, Malang: Setara Pres, 2019

[8].James W. Nickel, "Making Sense Of Human Rights Philosophical Reflection", University of California Press, 1987, California, Human Rights Philosophical Reflections on the Universal Declaration of Human Rights, Jakarta:, PT. Gramedian Pustaka Utama, 1996

[9].Jimly Asshiddiqie, "Women's Constitutional Rights and the Challenges of Enforcement", presented at the Public Dialogue and National Consultation of Komnas Perempuan "Women and the Constitution in the Era of Regional Autonomy: Challenges and Common Attitudes", Jakarta, 27 November 2007

[10]. Jimly Asshiddiqie, Introduction to Constitutional Law, Jakarta: Rajawali Pres Publisher, 2014.

[11]. Majda El Muntaj, Human Rights in the Indonesian Constitution: from the 1945 Constitution to the Amendments to the 1945 Constitution of 2002, Jakarta: Kencana, 2017.

[12]. Sri Hastuti Puspitasari, "Protection of Human Rights in a State Society", Journal of Law Ius Quia Iustum, Vol. 7 No. 14. August 2000, Art no. 4993, doi: 10.20885 / iustum.vol.7.iss14.art.3
[13]. Sunarno, “A Democratic Rule of Law”, medianeliti.com, (Online) https://media.neliti.com/media/publications/235 03-ID-negara-hukum-yang-demokratis.pdf

[14]. Titik Triwulan Tutik, Indonesian Constitutional Law Construction Post Amendment to the 1945 Constitution, Jakarta: Kencana Prenada Media Group, 2010.

[15]. Ujang Charda, Citizenship Education for Higher Education, Depok: PT. RajaGrafindo Persada, 2017 